\title{
DESAIN BAHAN AJAR BERBASIS AGRIBISNIS PENGOLAHAN HASIL PERTANIAN
}

\author{
Ai Tusi Fatimah1, Sri Solihah² \\ 1,2 Program Studi Pendidikan Matematika, Universitas Galuh, Jl. R. E. Martadinata No.150, Ciamis, Indonesia \\ Email: ${ }^{1}$ aitusifatimah@unigal.ac.id
}

\begin{abstract}
Vocational school education has a special purpose, namely to prepare students, especially to work following their field of expertise. Mathematics subjects support these objectives which are characterized by graduate competencies, namely students have an understanding of mathematics in carrying out tasks according to their expertise. This understanding of mathematics will be realized if the teacher integrates mathematical concepts with the needs of each area of expertise in mathematics teaching materials. The purpose of this study was to design mathematics teaching materials aimed at students of SMK Agribusiness Processing of Agricultural Products (APHP). The research method used is ADDIE (analysis, design, development, implementation, evaluation). Teaching materials are designed based on APHP contexts, basic competencies in mathematics subjects, and mathematical understanding abilities. The resulting teaching material is in the form of a worksheet that has a peculiarity, namely the problem situation presented on each worksheet is the context of the APHP for the production of vegetable processing. The implementation of teaching materials is carried out at one of the State Vocational Schools in Ciamis APHP Competency. Evaluation is carried out at each stage of the research to produce student worksheets that can be used for APHP SMK students.
\end{abstract}

Keywords: Agribusiness processing of agricultural products, teaching materials, vocational mathematics,

\begin{abstract}
ABSTRAK
Pendidikan SMK memiliki tujuan khusus yaitu mempersiapkan siswa bekerja sesuai dengan bidang keahliannya. Mata pelajaran matematika mendukung tujuan tersebut yang ditandai dengan kompetensi lulusan, yaitu siswa memiliki pemahaman matematika dalam melaksanakan tugas sesuai keahliannya. Pemahaman matematika tersebut akan terwujud apabila guru mengintegrasikan konsep matematika dengan kebutuhan dari masing-masing bidang keahlian pada bahan ajar matematika. Tujuan dari penelitian ini adalah untuk merancang bahan ajar matematika yang ditujukan untuk siswa SMK Agribisnis Pengolahan Hasil Pertanian (APHP). Metode penelitian yang digunakan adalah ADDIE (analysis, design, development, implementation, evaluation). Bahan ajar dirancang berlandaskan konteks-konteks APHP, kompetensi dasar mata pelajaran matematika, dan kemampuan pemahaman matematis. Bahan ajar yang dihasilkan berbentuk lembar kerja yang memiliki kekhasan yaitu situasi masalah yang disajikan pada setiap lembar kerja merupakan konteks APHP produksi pengolahan hasil nabati. Implementasi bahan ajar dilakukan di salah satu SMK Negeri di Kabupaten Ciamis pada Kompetensi APHP. Evaluasi dilakukan pada setiap tahapan penelitian sehingga menghasilkan lembar kerja siswa yang dapat digunakan untuk siswa SMK APHP.
\end{abstract}

Kata kunci: Agribisnis pengolahan hasil pertanian, bahan ajar, matematika kejuruan

Dikirim: 14 November 2020; Diterima: 30 Januari 2021; Dipublikasikan: 30 Maret 2021

Cara sitasi: Fatimah, A. T., \& Solihah, S. (2021). Desain bahan ajar berbasis agribisnis pengolahan hasil pertanian. Teorema: Teori dan Riset Matematika, 6(1), 25-33.

Doi: http://dx.doi.org/10.25157/teorema.v6i1.4487 


\section{PENDAHULUAN}

Pengembangan bahan ajar telah banyak dilakukan untuk siswa SMK. Misalnya pengembangan modul pembelajaran matematika berbasis pendekatan konstruktivisme pada materi logaritma (Supardi et al., 2019), pengembangan bahan ajar matematika berbasis pendekatan kontekstual (Rahim \& Wahyuni, 2012), pengembangan bahan ajar matematika berbasis komputer menggunakan flipbook maker disertai nilai islam pada materi peluang (Munandar \& Rizki, 2019). Namun demikian, pengembangan bahan ajar untuk siswa SMK yang berbasis keahlian masih sangat jarang ditemukan. Padahal, pengembangan bahan ajar berbasis keahlian kejuruan sangat memungkinkan dilakukan. Misalnya Coben \& Weeks (2014) mengembangkan bahan ajar mulai dari perencanaan hingga penilaian yang terintegrasi dengan bidang keahlian pada konteks perhitungan dosis obat.

Pengembangan bahan ajar matematika yang terkoneksi dengan bidang keahlian merupakan upaya untuk mendukung tujuan pendidikan SMK. Undang-undang Nomor 20 Tahun 2003 menyatakan bahwa pendidikan matematika bertujuan untuk mempersiapkan siswa terutama bekerja sesuai bidang keahliannya. Namun, kenyataan di lapangan masih bertolak belakang dengan tuntutan undang-undang tersebut. Bahan ajar matematika yang bersesuaian dengan bidang keahlian masih sangat jarang ditemukan. Lebih jelas lagi tuntutan mata pelajaran mendukung keahlian siswa tercantum pada Permendikbud Nomor 34 Tahun 2018 yang menyatakan bahwa standar kelulusan siswa diantaranya memiliki kemampuan menggunakan matematika dalam melaksanakan tugas sesuai keahliannya.

Matematika yang dipelajari oleh siswa kejuruan dapat dikatakan sebagai matematika kejuruan (Bakker, 2014). Untuk siswa SMK, pengetahuan matematika konseptual dalam suatu konteks keahlian yang praktis memiliki peran yang penting (Lacroix, 2014). Oleh karena itu, konsepkonsep teoritis matematika formal hendaknya dibuat konkrit untuk keperluan praktek siswa (Swanson \& Williams, 2014), matematika yang dikembangkan harus relevan dengan tempat kerja yang bersifat praktis, teoritis, formal, dan informal (FitzSimmons \& Björklund Boistrup, 2017).

Langkah-langkah awal menuju pengintegrasian matematika dengan suatu bidang keahlian sudah dilakukan oleh peneliti, seperti analisis terhadap kebutuhan matematika pada suatu kompetensi keahlian, dan menganalisis kemampuan matematis siswa untuk menyelesaikan tugas matematis dengan konteks keahlian. Fatimah \& Zakiah (2019) menganalisis kebutuhan matematika pada SMK Teknik dan Bisnis Sepeda Motor. Fatimah \& Solihah (2020a) menganalisis peran matematika pada mata pelajaran agribisnis pengolahan hasil pertanian. Fatimah et al. (2019) menganalisis kemampuan penalaran kreatif dan imitatif siswa dalam memecahkan tugas dalam konteks agribisnis hortikultura. Fatimah \& Zakiah (2018) menganalisis kelancaran prosedural siswa dalam memecahkan tugas dalam konteks pemasaran. Langkah awal tersebut merupakan suatu upaya yang harus terus dikembangkan mengingat spektrum keahlian SMK hingga saat ini berjumlah 146 kompetensi keahlian. Banyaknya spektrum keahlian menjadi tantangan tersendiri bagi para peneliti karena setiap kompetensi keahlian memerlukan konsep matematika yang berbeda untuk memecahkan masalahnya.

Pengintegrasian matematika dan suatu keahlian kejuruan dapat dikatakan sulit. Hal tersebut terlihat dari sedikitnya peneliti yang terjun pada area penelitian ini. Bakker menyatakan tiga alasan kurang minatnya peneliti pada area ini, yaitu peneliti harus memiliki kemampuan hybrid (matematika dan kejuruan), sekolah kejuruan berbeda bentuk di setiap negara, dan matematika kejuruan dianggap bukan matematika (Bakker, 2014). Tantangan ini tentunya harus diantisipasi dengan sebuah metodologi yang memungkinkan terwujudnya pengintegrasian ini sehingga akan berdampak pada semakin tumbuhnya minat untuk mengembangkan berbagai sumber belajar untuk mewujudkan tujuan pendidikan di SMK.

Berdasarkan uraian tersebut, maka peneliti sangat tertarik untuk merancang bahan ajar dari salah satu spektrum keahlian SMK yaitu Agribisnis Pengolahan Hasil Pertanian (APHP). Berdasarkan penelusuran terhadap bahan ajar sebelumnya, belum ditemukan bahan ajar 
matematika yang secara spesifik mengintegrasikan konteks APHP dan konsep matematika ini. Analisis baru dilakukan terkait peran matematika pada mata pelajaran APHP (Fatimah \& Solihah, 2020b). Oleh karena itu, tujuan dari penelitian ini adalah untuk mendesain bahan ajar matematika berbasis APHP.

\section{METODE PENELITIAN}

Penelitian ini menggunakan metode ADDIE (Branch, 2011). Metode ini merupakan salah satu desain instruksional untuk pengembangan produk. ADDIE (analysis, design, development, implementation, evaluation) merupakan tahapan penelitian pada penelitian ini. Setiap tahapan penelitian ini menggunakan pendekatan kualitatif, sehingga terjadi modifikasi pada setiap tahapannya sesuai dengan tujuan perancangan bahan ajar.

Tahap analisis dilakukan pada aspek kebutuhan matematika pada APHP dan keterkaitannya dengan konsep matematika atau ruang lingkup materi matematika. Analisis kebutuhan matematika mengacu pada hasil penelitian (Fatimah \& Solihah, 2020b) yang kemudian dianalisis lebih lanjut keterkaitannya dengan ruang lingkup materi dan kompetensi dasar yang akan digunakan pada perancangan bahan ajar.

Tahap desain bahan ajar dilakukan dengan menetapkan kompetensi dasar mata pelajaran matematika, topik/ruang lingkup materi, kemampuan berpikir matematis, konteks APHP yang digunakan, dan bentuk bahan ajar yang akan dihasilkan. Kompetensi dasar matematika yang dipilih adalah 3.1 dan 4.1 pada materi bilangan bentuk pangkat, akar, dan logaritma. Kemampuan berpikir matematis yang dituju adalah pemahaman matematis dalam menyelesaikan masalah dalam konteks APHP. Konteks yang digunakan adalah produksi pengolahan hasil pertanian. Bentuk bahan ajar adalah lembar kerja siswa. Untuk menghasilkan lembar kerja ini, dilakukan terlebih dahulu perancangan tugas matematis yang mengintegrasikan konteks APHP dengan konsep bilangan bentuk pangkat, akar, dan logaritma.

Tahap pengembangan dilakukan untuk menghasilkan bahan ajar dalam bentuk lembar kerja siswa. Pada tahap ini dimulai dari penentuan isi lembar kerja sampai menghasilkan lembar kerja yang siap diimplementasikan kepada siswa. Sebelum lembar kerja diimplementasikan terlebih dahulu dilakukan validitas konten dan konstruks. Validitas konten dilakukan bersama-sama dengan ahli di bidang pendidikan matematika dan guru matematika SMK untuk melihat kesesuaian isi lembar kerja dengan standar isi dan standar kompetensi mata pelajaran matematika di SMK. Validitas konstruk dilakukan oleh guru APHP untuk melihat kesesuaian konteks APHP pada setiap masalah atau situasi yang disajikan dalam lembar kerja. Setelah itu, lembar kerja diujicobakan secara terbatas ( 3 orang siswa) untuk melihat keterbacaan lembar kerja.

Tahap implementasi dimulai dari persiapan sampai pelaksanaan implementasi. Tahap persiapan dilakukan oleh peneliti dengan melakukan observasi dan koordinasi terhadap guru matematika, observasi tentang karakteristik siswa dan tempat implementasi, serta membuat protokol observasi. Pada tahap pelaksanaan, data yang dicatat/direkam selama observasi dan dibuat dalam bentuk catatan lapangan yang terdiri dari deskripsi subjek dan catatan reflektif. Observer sebanyak 3 orang (2 peneliti dan 1 orang guru matematika) yang berperan sebagai pengamat non-partisipan. Selain observasi, untuk lebih mendalami pemahaman matematis siswa dalam menyelesaikan masalah dalam konteks APHP, maka peneliti melakukan wawancara terhadap siswa.

Evaluasi dilakukan pada setiap tahapan penelitian. Evaluasi pada tahap analisis fokus pada keterkaitan antara konteks APHP dan konsep/ruang lingkup materi matematika. Evaluasi tahap desain fokus pada situasi/masalah tugas matematis. Tahap pengembangan fokus pada struktur isi dari lembar kerja siswa. Evaluasi tahap analisis, desain, dan pengembangan dilakukan bersamasama dengan partisipan yang terdiri dari ahli pendidikan matematika (1 orang), guru APHP (2 orang), dan guru matematika (1 orang). Masing-masing partisipan memberikan penilaian terhadap lembar kerja yang dihasilkan pada lembar yang telah disediakan. Penilaian dengan skala sangat baik, baik, cukup, dan kurang pada masing-masing tugas matematis dan isi lembar kerja 
(kompetensi dasar dan indikator yang dicapai, rekapitulasi penilaian, bagian utama, dan alternatif jawaban tugas). Evaluasi secara khusus dilakukan pada tahap implementasi. Evaluasi difokuskan pada kemampuan pemahaman siswa pada penyelesaian masalah di lembar kerja. Melalui evaluasi ini, kita dapat melihat keberhasilan desain bahan ajar (lembar kerja) yang telah dirancang. Adapun indikator kemampuan pemahaman siswa dalam menyelesaikan masalah dalam lembar kerja adalah:

(1) memahami konteks masalah APHP pada pada setiap tugas matematis yang disajikan; (2) menghubungkan konteks masalah APHP dengan konsep matematika yang dibutuhkan untuk mendapatkan solusi; dan (3) melakukan prosedur matematis untuk mendapatkan solusi.

\section{HASIL DAN PEMBAHASAN \\ Tahap Analisis}

Hasil analisis keterkaitan antara peran matematika dan konsep atau ruang lingkup materi matematika mengacu pada hasil penelitian (Fatimah \& Solihah, 2020b). Peran matematika pada APHP pada penelitian ini dibatasi pada produksi pengolahan hasil nabati. Tabel 1 merangkum konteks-konteks produksi pengolahan hasil nabati dan konsep atau ruang lingkup materi matematika.

Tabel 1. Peran matematika pada mata pelajaran produksi pengolahan hasil nabati

\begin{tabular}{ll}
\hline \multicolumn{1}{c}{ Konteks APHP } & \multicolumn{1}{c}{ Konsep matematika/Ruang lingkup materi } \\
\hline Menghitung kebutuhan alat produksi & Bilangan dan operasinya \\
Menghitung kebutuhan bahan produksi & Bilangan dan operasinya, konversi satuan \\
Menghitung analisis usaha & Bilangan dan operasinya, aljabar \\
Mengukur ketebalan bahan & Bilangan dan operasinya \\
Menghitung prosentase bahan tambahan & Bilangan dan operasinya \\
\hline
\end{tabular}

\section{Tahap Desain}

Bahan ajar yang dirancang pada penelitian ini adalah kompetensi 3.1 dan 4.1 dengan ruang lingkup materi bilangan bentuk pangkat, akar, dan logaritma. Kompetensi ini diperuntukkan bagi siswa kelas $X$ semester 1. Perancangan bahan ajar dimulai dengan memilih peran APHP yang akan digunakan pada situasi dan tujuan perancangan tugas matematis disajikan pada Tabel 2.

Tabel 2. Konteks APHP pada situasi dan tujuan perancangan tugas matematis

\begin{tabular}{|c|c|c|}
\hline Konteks APHP & Situasi tugas matematis & Tujuan perancangan tugas \\
\hline $\begin{array}{l}\text { Menghitung kebutuhan alat } \\
\text { produksi }\end{array}$ & Mesin pencampur kopi & Siswa memahami konsep konsep akar \\
\hline \multirow[t]{3}{*}{$\begin{array}{l}\text { Menghitung kebutuhan } \\
\text { bahan produksi }\end{array}$} & $\begin{array}{l}\text { Bahan-bahan pengolahan manisan } \\
\text { kedondong }\end{array}$ & $\begin{array}{l}\text { Siswa membangun pemahaman konsep } \\
\text { bentuk pangkat }\end{array}$ \\
\hline & Gula sebagai bahan utama & Siswa memahami konsep pangkat \\
\hline & pengolahan buah-buahan & Siswa membangun pemahaman konsep akar \\
\hline $\begin{array}{l}\text { Menghitung prosentase } \\
\text { bahan tambahan }\end{array}$ & $\begin{array}{l}\text { pH larutan bahan produksi } \\
\text { pengolahan buah-buahan }\end{array}$ & Siswa memahami konsep logaritma \\
\hline \multirow[t]{3}{*}{ Menghitung analisis usaha } & $\begin{array}{l}\text { Panen buah sebagai bahan utama } \\
\text { pengolahan hasil nabati }\end{array}$ & $\begin{array}{l}\text { Siswa memahami konsep sifat-sifat bentuk } \\
\text { pangkat }\end{array}$ \\
\hline & $\begin{array}{l}\text { Panen umbi-umbian sebagai bahan } \\
\text { utama pengolahan hasil nabati }\end{array}$ & $\begin{array}{l}\text { Siswa memahami konsep bentuk pangkat } \\
\text { dalam bentuk notasi ilmiah }\end{array}$ \\
\hline & Waktu proses pemanasan manisan & $\begin{array}{l}\text { Siswa memahami konsep sifat-sifat bentuk } \\
\text { pangkat }\end{array}$ \\
\hline
\end{tabular}

Tabel 2 menunjukkan bahwa perancangan tugas dalam konsep bentuk pangkat memiliki banyak konteks APHP yang digunakan. Hal ini berdasarkan hasil evaluasi yang menunjukkan bahwa penggunaan representasi dalam bentuk pangkat lebih banyak dimungkinkan untuk digunakan dibandingkan dengan bentuk akar dan logaritma. Contoh desain tugas matematis dalam konteks APHP yaitu pada Gambar 1 dan Gambar 2. 
Kita akan membuat manisan buah basah berair. Bahan yang diperlukan terdiri dari:

Mangga/kedondong

Larutan gula pasir $50 \%$

Larutan kapur sirih 10\%

Larutan garam $10 \%$

Misalnya kita ingin membuat larutan gula pasir $50 \%$ dalam 10 liter, maka massa gula pasir yang diperlukan adalah:

$$
\frac{50}{100} \times 10=5
$$

Apabila kita ingin mendapatkan larutan gula pasir $50 \%$ sebanyak 10 liter maka diperlukan 5 kilogram gula pasir.

Satuan liter (I) dapat dikonversi (diubah) ke dalam satuan lainnya, misalnya mililiter (ml).

Sehingga,

$$
1 \mathrm{l}=1000 \mathrm{ml}
$$

$$
10 \mathrm{l}=10000 \mathrm{ml}
$$

Proses di atas adalah proses mengubah satuan. Dapatkah bentuk bilangan diubah?

10000 dapat diubah dalam bentuk berikut ini,

$10^{4}$ merupakan bentuk pangkat.

$$
10000=10 \times 10 \times 10 \times 10=10^{4}
$$

Gambar 1. Contoh desain membangun konsep bentuk pangkat melalui konteks pengolahan manisan buah

Seseorang akan melakukan pengolahan sari buah. Dalam resep disebutkan bahwa konsentrasi gula berkisar antara $12-14 \%$. Jika orang tersebut memiliki gula seberat $3 \mathrm{~kg}$ dan menginginkan konsentrasi sari buah adalah $13 \%$, maka:

a. Tentukan banyaknya air yang dibutuhkan untuk melarutkan gula tersebut (dalam satuan $\mathrm{ml}$ ).

b. Representasikan hasil bagian a dalam bentuk pangkat.

Gambar 2. Contoh desain pemahaman konsep bentuk pangkat dalam bentuk notasi ilmiah

\section{Tahap Pengembangan}

Tahap pengembagan menghasilkan bahan ajar dalam bentuk lembar kerja siswa. Tahap ini terdiri dari penentuan isi dan validasi lembar kerja sehingga dihasilkan lembar kerja yang siap diimplementasikan kepada siswa. Isi lembar kerja terdiri dari lembar judul, kata pengantar, daftar isi, kompetensi dasar dan indikator yang dicapai, rekapitulasi penilaian, bagian utama, alternatif jawaban tugas, dan daftar pustaka. Bagian utama meliputi tujuan pembelajaran dari setiap sub topik (pangkat, akar, logaritma), konstruksi konsep dari konteks APHP, dan tugas mandiri. Hasil validasi menunjukkan bahwa lembar kerja dalam kategori baik.

\section{Tahap Implementasi}

Implementasi lembar kerja berbasis APHP ini dilakukan di salah satu sekolah SMK APHP di daerah Ciamis. 12 siswa (5 laki-laki dan 7 perempuan) kelas $X$ terlibat dalam implementasi ini. Lembar kerja ini digunakan sebagai bahan ajar untuk membangun pengetahuan bilangan dalam bentuk pangkat, akar, dan logaritma serta sebagai bahan latihan terstruktur maupun mandiri. Pembelajaran yang digunakan oleh guru adalah pembelajaran berbasis masalah. Oleh karena itu, lembar kerja ini sangat membantu proses pembelajaran berbasis masalah karena konteks-konteks yang disajikan dalam tugas matematis berbasis masalah APHP. Selama implementasi berlangsung, peneliti dan guru matematika melakukan observasi untuk melihat kemampuan pemahaman matematis siswa dalam menyelesaikan masalah pada lembar kerja yang disajikan. Rangkuman hasil observasi disajikan dalam Tabel 3.

Tabel 3. Catatan lapangan observasi implementasi lembar kerja

\section{Deskripsi subjek}

Siswa membaca lembar kerja sedikit demi sedikit dan mengulang-ulang bacaannya.

Sebagian besar siswa dapat merepresentasikan kalimat tugas pada bentuk matematis.

Siswa mencari informasi terkait konversi satuan, sebagian bertanya pada temannya sebagian lagi mencarinya melalui internet.

\section{Catatan reflektif}

Siswa berusaha memahami situasi tugas, memahami konteks APHP pada setiap kalimat pada tugas.

Siswa berusaha memahami hubungan konteks tugas pada konsep matematika.

Siswa memahami prosedur untuk mencapai solusi 
Lanjutan Tabel 3.

Tabel 3. Catatan lapangan observasi implementasi lembar kerja

Deskripsi subjek

Siswa seringkali kesulitan menerapkan sifat-sifat bentuk pangkat, akar, dan logaritma. Penyelesaian tugas matematis sebelumnya seringkali menjadi ide untuk menyelesaikan tugas selanjutnya

Semua siswa lebih cepat menyelesaikan tugas dalam konteks yang sederhana dan melibatkan sedikit konsep matematika.
Catatan reflektif

Siswa memahami konsep dari tugas-tugas yang disajikan.

Siswa perlu pembiasaan diberikan tugas matematis dalam beragam konteks APHP

Setelah siswa menyelesaikan lembar kerja, peneliti kemudian melakukan wawancara untuk mengkonfirmasi hasil observasi. hasil wawancara menunjukkan bahwa siswa yang dapat menyelesaikan tugas dengan benar adalah siswa yang memahami setiap konteks pada lembar kerja, mampu menghubungkan konteks kalimat pada konsep matematika, dan melakukan prosedur matematis dengan benar. Adapun siswa yang belum berhasil menyelesaikan tugas dengan benar adalah siswa yang kesulitan menghubungkan beberapa konsep matematis untuk menghasilkan solusi. kesulitan tersebut terutama penggunaan sifat-sifat bentuk pangkat, akar, dan logaritma.

\section{Tahap Evaluasi}

Hasil tahap analisis, desain, pengembangan, dan implementasi lembar kerja digunakan sebagai bahan evaluasi untuk perbaikan lembar kerja. Perbaikan lembar kerja pada penyajian tugastugas matematis sehingga lebih dapat membangun pengetahuan konsep bilangan dalam bentuk pangkat, akar, dan logaritma dari pengalamannya selama menyelesaikan tugas. Lembar kerja ini sudah mendapatkan ISBN (Fatimah \& Solihah, 2020a).

\section{PEMBAHASAN}

Desain bahan ajar berbasis APHP ini memiliki kekhasan yaitu konteks-konteks yang disajikan sesuai dengan kompetensi keahlian siswa SMK APHP. Hal ini mendukung standar kelulusan siswa SMK terkait kemampuan siswa dalam memahami matematika dalam penyelesaian masalah-masalah di tempat kerja (Permendikbud, 2018). Konteks-konteks APHP ini perlu dianalisis terlebih dahulu karena konsep matematika pada suatu konteks seringkali tidak terlihat. Williams \& Wake (2007) menyatakan bahwa matematika di tempat bersifat black box. Oleh karena itu, analisis peran matematika pada APHP diperlukan untuk mengidentifikasi konsep apa saja yang diperlukan dalam penyelesaian masalah APHP.

Tabel 1 menunjukkan bahwa bilangan dan operasinya merupakan konsep matematika yang dominan muncul pada setiap konteks peran matematika pada APHP. Jika ditelisik pada kompetensi mata pelajaran matematika di SMK APHP, maka terdapat satu kompetensi yang berhubungan langsung dengan bilangan yaitu kompetensi 3.1 dan 4.1. Kompetensi tersebut berhubungan dengan topik bilangan berpangkat, bentuk akar dan logaritma. Jika ditelisik pada standar matematika sekolah (National Council of Teachers of Mathematics, 2000), standar bilangan dan operasinya meliputi kemampuan memahami bilangan, cara merepresentasikan bilangan, hubungan antar bilangan, sistem bilangan, makna operasi dan hubungannya, menghitung dengan lancar dan membuat perkiraan yang masuk akal. Bilangan dan operasinya pada konteks APHP berhubungan dengan representasi bilangan, operasi bilangan, menghitung dengan lancar, dan membuat perkiraan yang masuk akal.

Konteks-konteks APHP yang tergali pada tahap analisis tersebut kemudian digunakan sebagai situasi-situasi dalam desain bahan ajar. Situasi APHP tersebut bersifat kontekstual untuk mendukung pembelajaran berbasis masalah yang digunakan oleh guru matematika di kelas tersebut. Situasi yang bersifat kontekstual ini dapat menghubungkan matematika dengan kegiatan yang sesuai dengan tugas keahlian siswa (Sáenz, 2009). Konteks masalah yang dipilih dan digunakan dalam desain bahan ajar ini adalah konteks pengolahan hasil nabati. Konteks ini 
berhubungan dengan produksi pengolahan buah-buahan, sayuran, kacang-kacangan, serealia, dan umbi-umbian.

Desain bahan ajar berupa lembar kerja diawali dengan desain tugas matematis yang mengacu pada pendapat Johnson et al. (2017). Terdapat dua tujuan desain tugas matematis pada penelitian ini yaitu membangun pemahaman konsep matematis dan memberi kesempatan pada peserta didik untuk mengerjakan tugas dalam situasi APHP. Tugas matematis ini terdapat pada bagian utama lembar kerja siswa yaitu pada pemaparan konsep bilangan bentuk pangkat, akar, dan logaritma serta pada tugas mandiri. Pada tugas mandiri, konteks-konteks APHP diperkaya sehingga memungkinkan siswa mendapatkan kemampuan pemahaman matematis yang lebih mendalam dalam penyelesaian berbagai masalah konteks APHP.

Hasil implementasi menunjukkan bahwa siswa dapat menghubungkan konteks APHP dan konsep matematika. Penelitian sebelumnya menunjukkan bahwa konteks dapat mendukung kemampuan pemahaman matematis siswa (Fatimah et al., 2020), kemampuan penalaran (Fatimah et al., 2019), serta kemampuan pemahaman dan penalaran matematis secara bersama-sama (Fatimah \& Prabawanto, 2020). Oleh karena itu, desain tugas menjadi bagian penting dalam membiasakan siswa mengintegrasikan berbagai masalah dalam konteks APHP dengan konsepkonsep matematika.

Hasil evaluasi menuntun perbaikan lembar kerja terutama pada membangun pengetahuan konsep matematis. Hal tersebut terlihat dari hasil implementasi yang menunjukkan bahwa tugas mandiripun dapat dijadikan sarana untuk membangun beragam konsep dalam menyelesaikan tugas. Lebih jauh lagi, perancangan bahan ajar untuk siswa SMK hendaknya memperhatikan karakteristik peserta didik dan bentuk pembelajaran yang disajikan (Fatimah, 2018). Secara operasional, bahan ajar merupakan representasi dari rencana pembelajaran yang secara khas diperuntukan bagi siswa SMK (Fatimah \& Amam, 2018).

\section{KESIMPULAN}

Desain bahan ajar bagi siswa SMK memiliki karakteristik yang khas yaitu pada pengintegrasian konteks-konteks keahlian kejuruan dan konsep-konsep matematis. Bahan ajar untuk siswa SMK APHP tentunya dirancang dengan melibatkan konteks-konteks APHP. Konteks tersebut diantaranya adalah perhitungan kebutuhan alat dan bahan, analisis usaha, proses pengolahan (misal ketebalan dan pengeringan bahan), dan penyimpanan hasil produksi. Kontekskonteks tersebut dapat digunakan dalam desain bahan ajar pada aspek konstruksi konsep matematis maupun tugas matematis yang disajikan dalam lembar kerja siswa. Konteks-konteks yang disajikan tersebut dapat mendorong siswa pada kemampuan pemahaman konsep matematis. Selain itu, konteks dapat mendukung pemahaman matematis dalam menyelesaikan masalah dalam konteks yang sesuai dengan keahlian siswa.

\section{REKOMENDASI}

Banyaknya konteks-konteks APHP yang bersesuaian dengan kompetensi dasar mata pelajaran matematika memungkinkan dikembangkannya bahan ajar dalam konteks yang beragam untuk memenuhi bahan ajar matematika yang bersesuaian dengan keahlian siswa. Selain itu, desain bahan ajar pada penelitian ini hanya dalam ruang lingkup materi bilangan bentuk pangkat, akar dan logaritma. Oleh karena itu, penelitian ini dapat membuka penelitian-penelitian berikutnya untuk mengembangkan bahan ajar lainnya yang dapat digunakan oleh siswa SMK APHP.

\section{UCAPAN TERIMAKASIH}

Terima kasih kepada DRPM Kementerian Riset, Teknologi, dan Pendidikan Tinggi atas pendanaan PDP tahun 2020. 


\section{DAFTAR PUSTAKA}

Bakker, A. (2014). Characterising and developing vocational mathematical knowledge. Educational Studies in Mathematics, 86(2), 151-156. https://doi.org/10.1007/s10649-014-9560-4.

Branch, R. M. (2011). Instructional design. Instructional Design. https://doi.org/10.4018/978-1-60960503-2

Coben, D., \& Weeks, K. (2014). Meeting the mathematical demands of the safety-critical workplace: medication dosage calculation problem-solving for nursing. Educational Studies in Mathematics, 86(2), 253-270. https://doi.org/10.1007/s10649-014-9537-3.

Fatimah, A. T. (2018). Pedagogik matematika di sekolah vokasi. Jurnal Wahana Pendidikan, 5(4), 18.

Fatimah, A. T., \& Amam, A. (2018). Rencana pelaksanaan pembelajaran matematika di sekolah menengah kejuruan. Jurnal Penelitian dan Pembelajaran Matematika, 11(2). https://doi.org/10.30870/jppm.v11i2.3756.

Fatimah, A. T., \& Zakiah, N. E. (2018). Kelancaran prosedural matematis dalam pemecahan masalah konteks pemasaran. Mathline, 3(2), 141-150.

Fatimah, A. T., \& Zakiah, N. E. (2019). Matematika pada kompetensi teknik dan bisnis sepeda motor. JUMLAHKU: Jurnal Matematika IImiah STKIP Muhammadiyah Kuningan, 5(1), 31-47. https://doi.org/10.33222/jumlahku.v5i1.584.

Fatimah, A. T., \& Prabawanto, S. (2020). Mathematical understanding and reasoning of vocational school students in agriculture-based mathematical tasks. Journal for the Education of Gifted Young Scientists, 8(2), 701-712. https://doi.org/10.17478/JEGYS.702884.

Fatimah, A. T., Pramuditya, S. A., \& Wahyudin, W. (2019). Imitative and creative reasoning for mathematical problem solving (in context horticultural agribusiness). Journal of Physics: Conference Series, 1157(4). https://doi.org/10.1088/1742-6596/1157/4/042092

Fatimah, A. T., \& Solihah, S. (2020a). Bilangan bentuk pangkat, akar, dan logaritma: lembar kerja siswa berbasis agribisnis pengolahan hasil pertanian. CV. Tsaqiva Publishing. http://www.elsevier.com/locate/scp

Fatimah, A. T., \& Solihah, S. (2020b). Matematika pada mata pelajaran produksi pengolahan hasil pertanian. Umlahku Jurnal Matematika IImiah, 6(2), 176-187.

Fatimah, A. T., Wahyudin, W., \& Prabawanto, S. (2020). The role of agricultural contextual knowledge on the mathematical understanding of vocational students. Journal of Physics: Conference Series, 1521(3). https://doi.org/10.1088/1742-6596/1521/3/032020.

FitzSimons, G. E., \& Björklund Boistrup, L. (2017). In the workplace mathematics does not announce itself: towards overcoming the hiatus between mathematics education and work. Educational Studies in Mathematics, 95(3), 329-349. https://doi.org/10.1007/s10649-017-9752-9.

Johnson, H. L., McClintock, E., \& Hornbein, P. (2017). Ferris wheels and filling bottles: a case of a student's transfer of covariational reasoning across tasks with different backgrounds and 
features. ZDM - Mathematics Education, 49(6), 851-864. https://doi.org/10.1007/s11858-0170866-4.

Lacroix, L. (2014). Learning to see pipes mathematically: preapprentices' mathematical activity in pipe trades training. Educational Studies in Mathematics. https://doi.org/10.1007/s10649-0149534-6.

Munandar, A., \& Rizki, S. (2019). Pengembangan bahan ajar matematika berbasis komputer menggunakan flipbook maker disertai nilai islam pada materi peluang. AKSIOMA: Jurnal Program Studi Pendidikan Matematika, 8(1), 262-269. https://doi.org/10.24127/ajpm.v8i1.1957

National Council of Teachers of Mathematics. (2000). Principle and Standards for School Mathematics. The Council.

Permendikbud. (2018). Standar Kelulusan. Permendikbud No 34 Tahun 2018, 48(2), 123-154. https://www.academia.edu/38922036/The_Integration_of_Technology_into_English_Language _Teaching_The_Underlying_Significance_of_LMS_in_ESL_Teaching_despite_the_Ebb_and_F low_of_Implementation?email_work_card=viewpaper\%250Ahttps://doi.org/10.1155/2016/3159805\%25

Rahim, R., \& Wahyuni, D. (2012). Pengembangan bahan ajar matematika berbasis pendekatan kontekstual pada siswa smk negeri 5 medan. Jurnal MathEducation Nusantara, 53(9), 16891699.

Sáenz, C. (2009). The role of contextual, conceptual and procedural knowledge in activating mathematical competencies (PISA). Educational Studies in Mathematics, 71(2), 123-143. https://doi.org/10.1007/s10649-008-9167-8

Supardi, A. A., Gusmania, Y., \& Amelia, F. (2019). Pengembangan modul pembelajaran matematika berbasis pendekatan konstruktivisme pada materi logaritma pendahuluan salah satu mata pelajaran yang sangat penting di dunia pendidikan yakni matematika, dimana matematika merupakan ilmu yang bersifat universal. 10(1), 80-92.

Swanson, D., \& Williams, J. (2014). Making abstract mathematics concrete in and out of school. Educational Studies in Mathematics, 86(2), 193-209. https://doi.org/10.1007/s10649-014-95364

Williams, J., \& Wake, G. (2007). Black boxes in workplace mathematics. Educational Studies in Mathematics, 64(3), 317-343. https://doi.org/10.1007/s10649-006-9039-z 